International Journal of Small Business and Entrepreneurship Research

Vol.8, No.2, pp.1-16, April 2020

Published by ECRTD-UK

Print ISSN: 2053-5821(Print), Online ISSN: 2053-583X (Online)

\title{
WOMEN ENTREPRENEURSHIP AND GENDER EQUALITY AS A TOOL FOR SOCIAL TRANSFORMATION IN NIGERIA: EVIDENCE FROM SELECTED RICE FARMERS IN ANAMBRA EAST LOCAL GOVERNMENT
}

\author{
Muogbo, Uju S. PhD \\ Entrepreneurship Studies Department, Chukwuemeka Odumegwu Ojukwu University, Anambra \\ State Nigeria
}

\begin{abstract}
Women are viewed as the foundation of development of country and national economies as well as agents of social change. Nonetheless, traditions, beliefs and cultural norms limit women's capacity to acquire land and add to increase gender gaps in the quality and size of owned farmland. This kind of challenge made rural women to form different associations and groups, for instance, Rice Farmers Association, The Village Savings and Loan Associations and Daily Contribution association etc to empower themselves. This research examined the "Omambala" Women's Rice Farmers Association in South East area of Nigeria and how the women group has achieved social change around there. Majority of the members (over 94\%) are smallholder farmers. These women make consistent membership contributions, a social fund contributions and records are kept and the monies kept in a saving funds box, which is opened at a concurred time. Individuals members get their monies as per the sum contributed and the social fund contributions is used to purchase farm implements and inputs for members, build social amenities, reconstruct health care centers, re-construct dilapidated school blocks, offers grants to poverty stricken children and so forth. This paper examines the viability of this women rice farmers association as an instrument for gender balance and social transformation in Anambra State Nigeria. This research was done in villages at Anambra East local government where majority of the women are farmers and makes farming their major means of livelihood. 160 members and administrators of the group were interviewed using key informant interview and Focus Group Discussions. Data generated was analysed using simple percentage and frequency tables. Findings from the research shows that women farmers contributes a great deal to social change and economic development; traditions, beliefs and cultural norms influences the performance level of these women and climate change is an obstruction to their growth. The investigation in this manner prescribes that, to increase gender gaps, women ought to be permitted to possess farmlands; cultural norms that limits women from taking part completely in agriculture ought to be abrogated. Moreover, sufficient measures should to be taken by people and government to forestall flooding during raining season.
\end{abstract}

KEY WORDS: women entrepreneurs, cultural norms, traditional beliefs, social transformation, gender equality, village savings and loans association.

\section{INTRODUCTION}

In Nigeria, fifty seven percent of the rural work force are made up by women in inclusion to their ordinary home obligations. Despite women's role within the agricultural area, however, empirical 
International Journal of Small Business and Entrepreneurship Research

Vol.8, No.2, pp.1-16, April 2020

Published by ECRTD-UK

Print ISSN: 2053-5821(Print), Online ISSN: 2053-583X (Online)

evidence shows that they fall off at the back of men in regards agricultural productiveness in subSaharan Africa because of the gender disparities that persevere in connection with, control over and the usage of productive resources, for example, land, livestock, labour, education, expansion and financial administrations, and innovation. Traditions, beliefs and cultural norms limit women's capacity to inherit land and make contributions to boom gender gaps within the size and quality of possessed farmland. This research investigated the method of gender equality and social transformation by women in Nigeria. Essentially, it studied the 'Omambala' women rice farmers association who is generally smallholders farmers and in a group of pooling jointly their contributions to finance their agricultural productions and improve the way of life in their locality. This study is fundamental as it looked at the rice farmers association dynamics in helping women business, homes and farming activities. In contrast to various women organisation, the "Omambala" women group is explicitly extraordinary in their method of bringing development to its members and community at large. As a way of innovation, they preserve their savings in a 'Saving box' locked and keyed. It is only open at an agreed time for members to access the finances to support their various businesses, buy farm implements, build roads, and bring in primary health care facilities, support village scholarship scheme for indigent and infrastructures etc. Women in agriculture can play vital roles within the economic development if they have equal opportunity and access to resources. In Nigeria, small percent of women have access to financial services because of restricted land possession which serves as a major collateral to get credit facilities. Poor farmers and other individuals living in rural areas are not able to get credit or obtain deposit accounts from the formal financial organizations because of the reality they barely ever have legitimate proof of identity, land possession, address or employment. This makes it hard for them to take formal credit from any financial institution to aid their business and bring social change in their locality. Women are assumed to be dynamic savers whether through formal or casual methods (Kendall, 2010). Individuals from Women Rice Farmers Association make savings contributions to the pool and can likewise borrow from it. The group is built solely on member savings and interest rates from loans. Members do get one year of intensive training in businesses, administration, governance and cash control, which permits them to develop as independent and even enable them to establish various groups "(Brannen and Sheehan-Connor 2012)".

The Farmers Savings Association is a traditional savings group that has been into existence for a long time which is a self-selected group of individuals (generally unregistered) who pool their cash into a saving/resource pool. The establishment of the association requires no outside funding and operation is based on the Savings contributions made by its members. Group members of the farmer's savings association can borrow from the savings pool, and the cash is paid back with interest, making the cash to grow. Furthermore, they don't consider the improvement of their community rather focuses on the member's needs. In any case, with the 'Omambala' women group, their method of operating the farmers association is somewhat unique, as individuals members 
International Journal of Small Business and Entrepreneurship Research

Vol.8, No.2, pp.1-16, April 2020

Published by ECRTD-UK

Print ISSN: 2053-5821(Print), Online ISSN: 2053-583X (Online)

can't get loan from the 'Savings box' and part of the amount gathered is used to buy cultivating needs like, herbicides, spraying machines, cutlasses, manures for group members, reconstruct roads, bolsters essential primary health care, provides access to clean water, gives employments and support the training of the less privilege children. Historically, Anambra East Local Government Area is referred to as "Omambala" because they are surrounded by Omambala river and their farm land are known for bringing out good harvest during harvest season. Some of the villages that made up Omambala are Umueri, Aguleri, Umuoba-Anam, Igbariam, Atani, Ogwuaniocha, Igbariam, Nando etc. Engaging women financially, brings development, wealth creation and financial strengthening in Nigeria. Different research have contended that once women accessed credit, their financial capacities improved and this will positively impact on the family welfare (Rajan and Zingales, 1998; Levine, Loayza and Beck, 2000). Access to credit grows businesses, enables affordability of services, for example, health care, education and increase in way of life. It additionally diminishes risk and vulnerability which can assist with smooth consumption in a household. Kumar (2009) states that self-help groups are formed across nations as a successful technique for poverty alleviation, human development and social empowerment. To this end, this paper analyze the effect of the "Omambala" Women Rice Farmers Group operating activities on the social needs of the group as well as their families and communities. The research likewise, look at the kind of innovation that this group tries to embrace that appeared to be unique from the traditional farmers association usually in place. The rest of the paper is organized as follows; section two looks at empirical literature and the third section captured methodology including those of the study design and sampling selection, instruments and data collection procedure. The fourth section presents results and discussion of the study while the last section concludes.

\section{Problem Statement}

In manly managed society women's' right has been misjudged due to cultural, customary practices and beliefs which supports discrimination against women. Depending on traditional gender roles and child care commitments of women, some people have not conceptualized the possibility that women can serenely and suitably manage an enterprise successfully. In spite of the vital role women play in agricultural development in the nation, they are not really given any consideration by the government. Banks scarcely give them loans and they might be scarcely reached with improved seeds, fertilizer and other input (Saito and Spurling, 1992). Additionally, the women farmers have no or insignificant part within the decision-making system concerning agricultural development in the country. Gender disparity is as yet predominant in the agrarian segment and this comprises an obstruction to development, calling for an assessment of government guidelines on agriculture to all the components that place rural women farmers off guard, Michelle Bachelet, former President of Chile and ex-Executive Director of United Nations Women, expressed: "When women are empowered and can claim their rights and access to land, authority, opportunities and 
International Journal of Small Business and Entrepreneurship Research

Vol.8, No.2, pp.1-16, April 2020

Published by ECRTD-UK

Print ISSN: 2053-5821(Print), Online ISSN: 2053-583X (Online)

decisions, economies develop, food security is boosted and possibilities are enhanced for cuttingedge and future generations." Connected with those issues there is additionally the issue of climate change, which incorporates irregular rainfall, floods, droughts and tornados, whose aftermaths greatly affect rural women farmers and make their existence hard. Women in agriculture are faced with an assortment of difficulties which brings disappointments to a number of them, for example insufficient innovation, bad extension services, lack of land possession right, lack of access to credit facilities, cultural/religious restrictions, negative wellness, lack of good infrastructures and access to education and training.

Several investigations had been conducted on women in agrarian area in various parts of Nigeria however none were completed on women who are into rice cultivation, production and their association in "Anambra East Local government Area of Anambra State" Nigeria. Umunakwe et al (2017), studied on limitations to participation of women in agriculture Program in Aboh Mbaise Local Government Area of Imo State; Abayomi and Michael (2006) carried out a study on Gender and Research Attainment in Nigerian Agricultural Universities; Yemisi and Aisha (2009) analyzed Gender Issues in Agriculture and Rural Development in Nigeria: The Role of Women. Studies have additionally been completed on gender disparity, gender discrimination, gender inequality and economic development yet their findings and suggestions have not completely been implemented by the individuals concerned. The helplessness of Nigerian women is an incontestable truth despite the sanction on gender discrimination and unequal access to education, healthcare services, inadequate housing and employment. Against these backdrops, this research tends to study the contributions of women entrepreneurship and gender equality as an instrument for social transformation in Nigeria with reference to Omambala Women Rice Farmers Association.

\section{Objectives of the study}

Specifically, the following specific objectives guided the study;

1. To examine the level at which cultural practices and norms affect women rice farmers in Anambra State

2. To determine the degree at which religious beliefs affect women farmers in Anambra State

3. To determine the extent at which climate change, which includes irregular rainfall, floods, droughts and cyclones affects women farmers

4. To determine if women participation in agricultural activities can contribute to social transformation in Anambra State

\section{Research Questions}

Below are the research questions posed to guide the study 
International Journal of Small Business and Entrepreneurship Research

Vol.8, No.2, pp.1-16, April 2020

Published by ECRTD-UK

Print ISSN: 2053-5821(Print), Online ISSN: 2053-583X (Online)

1. To what level can cultural practices affect women rice farmers in Anambra State

2. To what degree can religious beliefs affect women farmers in Anambra State?

3. To what extent can climate change, which includes irregular rainfall, floods, droughts and cyclones, affect women rice farmers in Anambra State?

4. To what extent can women participation in agricultural activities contribute to social transformation in Anambra State?

\section{EMPIRICAL REVIEWS}

Over the years, women have set up more distinct roles in agriculture. Mostly, the degree of gender contribution in agricultural production differs across indigenous groups in Nigeria. In general, most research established that women participates fully in agricultural programme in their community. Umunakwe, Asiabaka, Nnadi, Ibe, and Okonya-Chukwu, (2018) stated in their study of women-in-agriculture programme in Aboh Mbaise local government area of Imo state Nigeria that all the WIA packages were available in the study area and women farmers participated in all of them. That major constraints of participation in WIA Programme were inadequate capital and illiteracy level. Therefore they recommend that the programme be sustained and up-scaled and credit facilities should be made available to women farmers.

Several studies have examined the impact of self-help group savings or village savings and loans association on the welfare of its members, money related sustenance it gives and various supports that this financing mechanism has outfitted to its members. In general, most research established that this self-help groups has prompted increment in the financial savings behaviour of members beforehand who didn't save and never thought of saving. Nsabagasani et al (2008) stated in a focus group discussion of a Village Savings and Loan group in Uganda that their involvement has encouraged increase in the members ability to mobilize savings and that group members are able to send their children to secondary school. Also, Cosmin (2009) assessed women's Self-help Groups (Group saving model/scheme) in Ethiopia and settled that this group has led to the women being focused on meeting and savings every week.

Through taking part in agriculture and belonging to the women farmers association, it has been found that access to finance has additionally influenced the prosperity of members in terms of healthcare financing and nourishment. The study of Cosmin (2009) found a momentous mish mash of health and nutrition education with group saving as weightily affecting the lives of the women who participate in such group programme. Thus, women give food, sustenance, nutrition, and educational materials to their kids. Kumar (2009), found that taking part in savings group activities helps the rural women to earn more income and improve social welfare and in this manner helps in accomplishing higher healthful security for them and their family. 
International Journal of Small Business and Entrepreneurship Research

Vol.8, No.2, pp.1-16, April 2020

Published by ECRTD-UK

Print ISSN: 2053-5821(Print), Online ISSN: 2053-583X (Online)

Education, autonomy of production, access to credit, market linkage improved women farmers in Niger State as uncovered by Abubakar, Olawale. Mathew, Fatima (2016). Their study was conducted to know the impact of adoption of innovative rice processing techniques of International Fund for Agricultural Development (IFAD), value chain development programme on profitability and empowerment. They analyzed the socio-economic qualities of the adopters of the advanced rice processing technique, decide their net returns, empowerment, and identified the limitations faced by these rural poor households.

There are gigantic advantages of women grouping and pooling. It was additionally discovered that women who participates in savings or self-help groups in different geographical areas brings about asset accumulation. Ranjula and Adel (2008) found that being a member of self-help groups for a long period of time positively impacts on asset creation as members of this women groups acquired different assets during savings activities. And that the training provided by the non-governmental organisation likewise helps in member asset creation drive.

Additionally, there are elements affecting rice farming production in Nigeria as stated by Osanyinlusi, and Adenegan (2015). Farm size, level of education and amount of fertilizer used, years of farming experience and quantity of seeds used, climate change and pest infestations and financial constraints had been ranked as the maximum challenging factors proscribing rice production inside the observe region. The study encouraged that extension services need to be intensified within the location to teach the farmers on an appropriate utility rate of fertilizer and seed rate per hectare.

\section{METHODOLOGY}

\section{Study Design}

To study the 'Omambala' women rice farmers association in Anambra East Local government of Nigeria, mixed method approach (qualitative and quantitative) was adopted. Qualitative approach used verbal communication, words and observations to express a reality that describes the group attitudes, behaviour and activities in a normal circumstance (Golafshani, 2003). Qualitative method were used basically in light of the requirement for a complex and in-depth comprehension of the issue from the perspective of the members in the group. The research got factual information by talking straight to the group members in an interview and administering questionnaire (which includes focus group discussion) which allows them to give data on their encounters and experiences with the group activities and funds. Quantitative method is a research instrument which requires a trust in figures and numbers that likewise captures opinions or ideas in a study (Kothari, 2004). Quantitative approach were used explicitly to give numbers and figures to help 
International Journal of Small Business and Entrepreneurship Research

Vol.8, No.2, pp.1-16, April 2020

Published by ECRTD-UK

Print ISSN: 2053-5821(Print), Online ISSN: 2053-583X (Online)

explain the issue under investigation and the qualitative method added value to the findings of this paper through clarification from the respondents.

\section{Sample selection, instruments and data collection procedure}

The purposive sampling procedure were used as respondents are group members from the 'Omambala' women rice farmers association. The objective of the study was duly explained to the respondents to obtain their permission before they take part in the study while simple random sampling technique was adopted to select the real respondents. In general, 160 respondents were chosen from various households across the eight different villages (Umueri, Aguleri, UmuobaAnam, Igbariam, Atani, Ogwuaniocha, Nando, and Nzam) along these lines, equivalent opportunity was given to each group to ensure reasonable representation and participation. 16 respondents were picked to partake for the focus group discussion and at the end 9 actually took part.

Focus group discussion were used to get qualitative information while an interviewer-administered questionnaire were used to gather quantitative data. Interviewer-administered questionnaire was adopted due to the illiteracy (could not read or right) rate among the respondents. The researcher read out the questionnaire to the respondents in their local language and recorded their responses properly. The Likert scale were used with a Calibration of Strongly Agree (SA), Agree (A), Undecided (U), and Disagree (D) for the response on research questions. Provisions were created for respondents to tick where appropriate and acceptable. Responses from the respondents were audio recorded and notes taken during the focus group discussion. In-depth clarifications were given to the respondents with these instruments, and responses were gathered from them regarding the matter. The information were subjected to approval checks and cross check to support the sequential responses. Descriptive statistics were adopted to depict the nature and appropriation of the information and the corrected data were analysed using STATA. Results were arranged and presented in the form of frequencies and percentages count. To complement the quantitative data, the qualitative data were copied in exactly the same words and analysed through content analysis bolstered with quotations from respondents.

\section{RESULTS AND DISCUSSION}

\section{Background information about the group}

The development of 'Omambala' women rice farmers association was a thought of the group leader which he brought on board to deliberate with one of his friend on the best way to support the women. The group began its activity in May 2015 with the name 'Omambala' which is the name of the towns that makes up Anambra East Local government. The group chairman thought of how the town has been backwards in developed, lacks present day facilities, social amenities, and how 
International Journal of Small Business and Entrepreneurship Research

Vol.8, No.2, pp.1-16, April 2020

Published by ECRTD-UK

Print ISSN: 2053-5821(Print), Online ISSN: 2053-583X (Online)

women struggle to secure some small amount of cash to help them during cultivating season, so he concluded that if after the season they can unite these women to make some contribution week by week or around four days interval and if it sustains, then the coming season they can use such contribution for their cultivating needs. The group began with just 30 individuals who were women and now have more than 500 members residing in Anambra East local government. With the achievement of the group some men indicated interest and joined them however the name despite everything remains 'Omambala' Women Rice Farmers Association. The chairman manages the group as the leader together with other three people who are secretary, treasurer and financial secretary. They attend meeting each one-week interval and makes contributions of any amount a member is willing to contribute. Aside from the member contribution, every member is to contribute necessarily a specific amount into the social/welfare coffers. This groups keeps records and the cash realised after each meeting is kept in a wooden 'Savings' box locked and keyed. After every six months, the 'Savings- box' is open and the sum realised is shared among the individuals as per what each member contributed and the total amount realized from the social/welfare contributions is used to manage the association needs, for community development and for the acquisition of cultivating items, for example, herbicides, pesticide, splashing machines, cutlasses, wellington boots, weedicide, and so forth for group members as requested by each member. In contrast to other Village association, this group doesn't give loans and different borrowings. In any case, members get the amount each one of them contributes when the savings box is open. The purpose behind not giving out credit is on the grounds that they observed that unlike other village association where loans are given, the loan takers most times default and which leads to breakdown of such groups.

From the interaction the researcher had with the chairman of the association together with few administrative members, it was gathered that the group has 6-point agenda to be accomplish within six years of formation. They tend to implement this agenda with social fund contributions they make weekly alongside other contributions from the members. The social fund is purely for social development of the community and buying of farm inputs for the members as they request. The agenda starts with building access roads that connects their farms with other villages and cities so that people who are interested to buy rice in large quantity can easily patronize them. The second plan is to introduce improved rice technologies production in their local government since majority of them are small holder farmers. The remaining plans are rebuilding the primary health care facility because they are living in a remote area and hospital is very far from them; rebuilding the only village school dilapidated block that was built in 1806; having access to clean water and taking up electricity project and inviting the human rights organisation to conduct a seminar to assist in gaining back the rights of women in their community. This women rice farmers association has been in existence since 2015 . 


\section{Descriptive statistics and distribution of variables}

The distribution of variables and descriptive statistics is shown in table 1 below. $80.6 \%$ of the association members are women while $9.4 \%$ are men. In all, $87.5 \%$ of the respondents are peasant farmers and the rest is either petty traders or engaged in other form of jobs. Majority of the group members are illiterates as $76.9 \%$ of them had no formal education and only $15 \%$ have primary education. The age brackets of the respondents indicate that $70 \%$ are within the age limit of 30 to 40 years of age. This is followed by $18.1 \%$ that are within 20 to 30 years with the rest either between 40 to 50 years bracket or above 50 years of age. The study indicates that $81.9 \%$ have their income levels range between $\$ 35,000$ - 100,000 (US\$100 to US\$300) and the remaining earns above 100.000 with only $3.1 \%$ earning beyond $\$ 200,000$. From the table, the distribution shows that the most of the women are poor. On marital status, $75.6 \%$ of the respondents are married with the rest being single, widowed or divorced.

\section{Table1: Descriptive statistics and distribution of variables}

\begin{tabular}{|l|l|l|l|}
\hline Variable & Response & figures & Percentages \\
\hline The group of the respondents & Umueri & 30 & 18.8 \\
& Aguleri & 25 & 15.6 \\
& Ogwuaniocha & 20 & 12.5 \\
& Umuoba-Anam & 15 & 9.4 \\
& Igbariam & 13 & 8.1 \\
& Nando & 20 & 12.5 \\
& Atani & 17 & 10.6 \\
& Nzam & 20 & 12.5 \\
\hline Total & & $\mathbf{1 6 0}$ & $\mathbf{1 0 0}$ \\
\hline
\end{tabular}

\begin{tabular}{|l|l|l|l|}
\hline Gender & Male & 31 & 19.4 \\
& Female & 129 & 80.6 \\
\hline Total & & $\mathbf{1 6 0}$ & $\mathbf{1 0 0}$ \\
\hline
\end{tabular}

\begin{tabular}{|l|l|l|l|}
\hline Occupation & Farming & 140 & 87.5 \\
& Petty Trading & 12 & 7.5 \\
& Other work & 8 & 5 \\
\hline Total & & $\mathbf{1 6 0}$ & $\mathbf{1 0 0}$ \\
\hline
\end{tabular}


International Journal of Small Business and Entrepreneurship Research

Vol.8, No.2, pp.1-16, April 2020 Published by ECRTD-UK

Print ISSN: 2053-5821(Print), Online ISSN: 2053-583X (Online)

\begin{tabular}{|l|l|l|l|}
\hline Education & No formal schooling & 123 & 76.9 \\
& Primary & 24 & 15 \\
& Secondary & 13 & 8.1 \\
& Higher & 0 & 0 \\
\hline Total & & $\mathbf{1 6 0}$ & $\mathbf{1 0 0}$ \\
\hline
\end{tabular}

\begin{tabular}{|l|l|l|l|}
\hline Age & $20-30$ & 29 & 18.1 \\
& $31-40$ & 112 & 70 \\
& $41-50$ & 10 & 6.3 \\
& 50 and Above & 9 & 5.6 \\
\hline Total & & $\mathbf{1 6 0}$ & $\mathbf{1 0 0}$ \\
\hline
\end{tabular}

\begin{tabular}{|l|l|l|l|}
\hline Income level & $1-50$ & 31 & 19.4 \\
& $51-100$ & 100 & 62.5 \\
& $101-200$ & 21 & 13.1 \\
& Above 200 & 8 & 3.1 \\
\hline Total & & $\mathbf{1 6 0}$ & $\mathbf{1 0 0}$ \\
\hline
\end{tabular}

\begin{tabular}{|l|l|l|l|}
\hline Marital Status & Single & 16 & 10 \\
& Married & 121 & 75.6 \\
& Widowed & 14 & 8.8 \\
& Divorced & 9 & 5.6 \\
\hline Total & & $\mathbf{1 6 0}$ & $\mathbf{1 0 0}$ \\
\hline
\end{tabular}

Source: Authors' computation based on field work data 
International Journal of Small Business and Entrepreneurship Research

Vol.8, No.2, pp.1-16, April 2020

Published by ECRTD-UK

Print ISSN: 2053-5821(Print), Online ISSN: 2053-583X (Online)

\section{Responses from the Research questions}

Table 2: Responses from the Respondents

\begin{tabular}{|l|l|l|l|l|l|l|}
\hline S/N & Variables & Disagree & Undecided & Agree & $\begin{array}{l}\text { Strongly } \\
\text { Agree }\end{array}$ & Remarks \\
\hline 1 & $\begin{array}{l}\text { Cultural norms restrain } \\
\text { women's ability to inherit } \\
\text { land }\end{array}$ & $3(1.9)$ & $15(9.4)$ & $\begin{array}{l}81 \\
(50.6)\end{array}$ & $61(38.10$ & Agree \\
\hline 2 & $\begin{array}{l}\text { People's belief affects the } \\
\text { performance level of } \\
\text { women rice farmers in } \\
\text { Anambra State }\end{array}$ & $2(1.3)$ & $24(15.0)$ & $\begin{array}{l}76 \\
(47.5)\end{array}$ & $56(35.0)$ & Agree \\
\hline 3 & $\begin{array}{l}\text { climate change, which } \\
\text { includes irregular rainfall, } \\
\text { floods, droughts and } \\
\text { cyclones, affect women } \\
\text { rice farmers in Anambra } \\
\text { State }\end{array}$ & $2(1.3)$ & $14(8.8)$ & $\begin{array}{l}67 \\
(41.9)\end{array}$ & $72(45.0)$ & $\begin{array}{l}\text { Strongly } \\
\text { Agree }\end{array}$ \\
\hline
\end{tabular}

Source: Field survey 2019

From the table 2 above, 50.6 percent of the respondents agree that cultural practices for instance, inability to own a land affects the performance of women rice farmers, $38.1 \%$ indicated strongly agree, while $9.4 \%$ undecided and $1.9 \%$ disagreed. The respondents agrees that culture plays a major role in the performance of women farmers in Anambra State. From the above responses, $47.5 \%$ of the respondents agree that people's belief is one of the major factors that affect women performance in agriculture in Anambra, 35\% strongly agree, 15\% were not too sure, while $1.3 \%$ disagreed. This implies that some of the religious beliefs are not favourable to women farmers in Anambra State. Additionally, $45 \%$ of the respondents strongly agree that climate change affects their farm produce especially during rainy season when there's flooding in their community, $41.9 \%$ agree, $8.8 \%$ undecided, and $1.3 \%$ disagree. The indication from the responses on the table above shows that these women suffers a lot during rainy season because water level rises and washes their farm products away. 
International Journal of Small Business and Entrepreneurship Research

Vol.8, No.2, pp.1-16, April 2020

Published by ECRTD-UK

Print ISSN: 2053-5821(Print), Online ISSN: 2053-583X (Online)

Table3: Response from the Respondents on group savings participation

\begin{tabular}{|l|l|l|l|l|}
\hline S/N & Variables & Yes & No & Total \\
\hline 1 & $\begin{array}{l}\text { Are you a member of any } \\
\text { other savings association } \\
\text { apart from women farmers } \\
\text { group savings }\end{array}$ & $140(87.5)$ & 160 \\
\hline 2 & $\begin{array}{l}\text { Does the group support } \\
\text { member's business }\end{array}$ & $\begin{array}{l}\text { 141(88.1) } \\
3\end{array}$ & $\begin{array}{l}\text { Participation in women } \\
\text { farmers savings groups has } \\
\text { help in expanding their } \\
\text { businesses }\end{array}$ & $139(86.9)$ \\
\hline
\end{tabular}

\section{Source: Field survey 2019}

The opinion of the respondents concerning the group savings participation is shown in the table 3 above, $87.5 \%$ of the respondents answered that they have no other means of savings aside the women rice farmers' savings group, $12.5 \%$ indicated they had another savings elsewhere. Accordingly, majority agreed that the farmers' association savings is the sole source of their income expectation and savings. $88.1 \%$ accepted that the association had made available some fund for them in to buy their farm inputs and they are glad joining the group. The participants attests that their involvement in the association has given them relieve compared to when they were not in any group.

\section{Achievements of the Women Rice Farmers Association (WRFA)}

The women rice farmers association (WRFA) has been into existence since 2015 and below are some of their achievements so far;

First year: The association through their social welfare contributions coffers reconstructed the 19.2 kilometer access road to their farm settlement. The road was constructed first thirty years ago during military era by Niger Dock Construction Company and has been in a bad shape for over ten years. No access roads has been a major challenge that faced the women farmers and entire community previously.

Second Year: Due to maternal and child mortality rate they rebuilt the only existing primary health care center in their village which serves as a hospital and as a maternity too. They partnered with a Non-governmental organisation (Save a Soul Foundation) in providing drugs in the facility.

Third Year: The women rice farmers association took it upon themselves and organized a competition for indigent children that wants to further their education. The competition was held in the eight villages first, the best four candidates were selected from each village then the grand 
International Journal of Small Business and Entrepreneurship Research

Vol.8, No.2, pp.1-16, April 2020

Published by ECRTD-UK

Print ISSN: 2053-5821(Print), Online ISSN: 2053-583X (Online)

finale took place at the village square where only selected children represented the primary, secondary and tertiary categories. In all, twelve children were selected, four for each category. After the selection, the finalist were given scholarship for four years each from the three categories and the old dilapidated school block was rebuilt and chairs provided for them all. The process is meant to continue every year.

Fourth Year: They provided a borehole for the community. The community overtime has faced the challenge of no access to clean water, children walk a long distance to fetch water from the only borehole provided by the government. Women Rice Farmers Association (WRFA) has touched many lives with their social welfare contributions and their involvement in community development. With this process, they have accomplished four out of six point agenda proposed by them and are willing to complete the six agenda before the sixth year of formation.

\section{Extract from Focus Group Discussion}

"A year ago I struggled to purchase farm input however couldn't because of paucity of funds but I am grateful to God with my participation in this group this year the story was different. I got a few inputs like weedicide and some amount of manure and even money that helped me... yes am upbeat (FGD discussant from Ogwuaniocha)"

"I am now able to increase my farm to three acre since I joined the women rice farmers association but before I joined my farm was just one acre. Since I expect some little money from my contribution and farm input of my choice, I generally have an objective of expanding my farm regardless of whether it is less than an acre of land, I do (FGD discussant from Umueri)".

"The Money I saved helped me in cultivating cost and acquisition of other farm input which is vital. It also helped in my social functions like attending burials and child dedication of my friend's child and making some form of cash donations. I additionally used part of the cash received to help my husband in buying a few books for my child's school. (FGD discussant from Nando)".

"Through my participation in this women group, I have acquired some radio set, which I used not to have. I always listen to programs from Authority F.M radio station every evening. This is good (FGD discussant from Aguleri)'”.

\section{SUMMARY OF FINDINGS, CONCLUSION AND RECOMMENDATIONS}

\section{Summary of Findings}

One remarkable finding is that most of the association members considers it to be more than a mere support to their business which is principally rice farming. They viewed it likewise as total 
International Journal of Small Business and Entrepreneurship Research

Vol.8, No.2, pp.1-16, April 2020

Published by ECRTD-UK

Print ISSN: 2053-5821(Print), Online ISSN: 2053-583X (Online)

financial liberty and bolster which help their living. Aside from business bolster mechanism, they are able to use some of the fund they saved with the association to acquire assets, pay for their children educational needs, healthcare financing, and social obligations.

Since getting loan from the bank to fund their rice farming business is very difficult as a result of their failure to provide a collateral, thus, the women formulate their own strategy by locally starting associations or groups that are self - introduced, self - manage, and unregistered to meet their demand for financial services and in the end improve their living conditions. This research looked at the Omambala Women rice Farmers Group to see the dynamics in this group savings ability and different methods for social change. The study found that this women association has brought development to their community and financial freedom to its members.

The cash contributed by the women group could help in poverty reduction, vulnerability and achieve economic growth (Rajan \& Zingales, 1998; Levine, Loayza \& Beck, 2000). This study found that most group members were able to fund their farming needs and consequently increase their farm size which leads to increase in incomes. Also, majority acknowledged that taking part in the group has assist them to acquire some assets, finance their child's education, healthcare payment and social support to them. This finding is in accordance with those of Dagnelie and LeMay-Boucher (2009) and Kumar (2009).

Additionally, other Village Savings Association groups that have functioned and collapsed might be as a result of mismanagement. This study found that some members who have been with other group acknowledged that those groups give out loans to members who at the end they are not able to payback their loans and this created problems for the group leading to its collapse.

\section{CONCLUSION}

From the study, the kind of savings and association adopted by Omambala brought an extraordinary help to the majority of them who are smallholder farmers. The accomplishment from the group is huge in that it has upheld their businesses, they use social contribution to purchase farm materials, have access to finance, decreased poverty rate, diminished women and child death rate and improve their way of life. The overall enthusiasm for the battle against destitution and vulnerability as captured in the Sustainable Development Goals (SDGs) has reflected in the carrying out of projects and strategies, especially in the developing nations that could expand financial inclusion for the rustic poor and serves in as a methods for access to credit. This study evaluated the Omambala Women Rice Farmers Group activities as they engaged in self-help group savings and financing of their businesses and transforming their community. The study was concern on the impact of this group activity on the welfare of its members and the suitability of 
International Journal of Small Business and Entrepreneurship Research

Vol.8, No.2, pp.1-16, April 2020

Published by ECRTD-UK

Print ISSN: 2053-5821(Print), Online ISSN: 2053-583X (Online)

the model they use, which is different from the well-known VSLA groups. Majority of the respondents are upbeat for being part of the group since it serves as an instrument for them to have access to credit, development and farm inputs. The respondents additionally confirm that the group's activities likewise serve as a way to expand their income level and improvement in welfare. As being part of the group, the members are able to acquire some assets as well as funding their children education with the money they get and to finance their healthcare needs.

\section{RECOMMENDATIONS}

The study subsequently recommends that suitable majors ought to be taken before rainy season begins to prevent harms from flood. Moreover, women should be given some privilege to take part completely in farming and access little grants from the government. Supporting the women rice farmers association should be encouraged. This support could be in terms of providing training on proper record keeping and the management as well as appropriate use of the members' savings. Additionally, business related trainings can be introduced to reinforce the development of income generating activities among the savings association members to make sure that there's no misappropriation of finance. There is likewise needing for women group to incorporate different activities like agricultural extension services into the group activities and this when done can prompt to maximization the benefits being obtained from the groups' activities.

\section{REFERENCES}

Anyango, E., Esipisu, E., Opoku, L., Johnson, S., Malkamaki, M. \& Musoke, C. (2007). "Village Savings and Loan Associations - Experience from Zanzibar". Small Enterprise Development, $18(1), 11-24$.

Brannen, C. (2010). "An impact study of the Village Savings and Loan Association (VSLA) programme in Zanzibar, Tanzania". A thesis submitted to the faculty of Wesleyan University, Middletown, Connecticut

Brannen, C \& Sheehan-Connor, D. (2012). "Evaluation of the Impact of Village Savings and Loan Associations Using a Novel Survey Instrument," Wesleyan Economics Working Papers 2012-003, Wesleyan University, Department of Economics.

Cosmin, F. (2009). "Women's Access to Credit, Income Generation and Adult Education in Ethiopia - Evaluating the member's Self-Help Group".

Golafshani, N. (2003). "Understanding reliability and validity in qualitative research". The Qualitative Report, 8, 597-607.

Hugh, A. (2002). "CARE International's Village Savings and Loan Programmes in Africa: Microfinance for the rural poor that work". Stuart Rutherford, Nagoya, Japan.

Kendall, J. (2010). “A Penny Saved: How Do Savings Accounts Help the Poor”? Available online at SSRN: http://ssrn.com/abstract=1982461 
Kumar S. D. (2009). "Participation in self -help group activities and its impacts; Evidence from South India"; The Bangladesh Development Studies, Vol XXXII, September, No.3.

Kothari, C.R. (2004). "Research Methodology, methods and techniques (2nd ed.). India, Jaipur": New Age International limited publishers.

Levine, R., Loayza, N. \& Beck, T. (2000). "Financial Intermediation and Growth: causality and causes". Journal of Monetary Economics, 46 (1), 31 - 71.

Rajan, R. G., \& Zingales, L. (1998). "Financial Dependence and Growth". American Economic Review, 88 (3) $559-586$

Ranjula B, S. and Adel, V. (2008). "Does Self Help Group Participation lead to Asset Creation? Working paper 2008:5, Department of Economics - UPPSALA University”

Saito, K.A and Spurling, D (1992). "Developing Agricultural Extension for Women Farmers. World Bank Discussion Paper No 156, Washington DC: World Bank”

Umunakwe, P.C., Asiabaka, C.C., Nnadi, F.N., Ibe, M.A. and Okonya-Chukwu, C.R. (2014). "Constraints to Participation of Women-in-Agriculture Programme in Aboh Mbaise Local Government area of Imo State, Nigeria”. European-American Journals 2014

Yemisi I. O. and Aisha A. M. (2009). "Gender Issues in Agriculture and Rural Development in Nigeria: The Role of Women”. Humanity \& Social Sciences Journal 4 (1): 19-30, 2009 ISSN 1818-4960

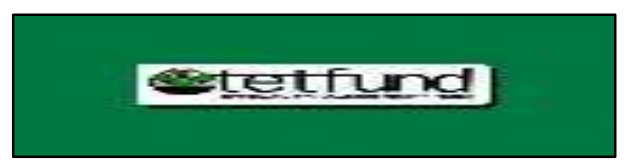

Sponsored by Tertiary Education Trust Fund Nigeria 